\title{
MODLITWA W UJĘCIU ŚW. JANA KASJANA
}

Modlitwa była zawsze jednym z istotnych ogniw, które łączyły i ożywiały Kościół we wszystkich wiekach. Podczas niej, przez nią i z niej chrześcijanie czerpali siłę, która pozwoliła im przetrwać prześladowania, pokusy, wzloty i upadki. Papież Jan Paweł II poświęcił temu zagadnieniu wiele miejsca w swoich przemówieniach na 1500-lecie urodzin św. Benedykta z Nursji. Ojciec święty stwierdza, że i dziś jest „nieodzowna potrzeba kontemplacji czyli modlitwy: skoro bowiem raz rozumiemy, że Bóg jest Absolutem i że my żyjemy w Absolucie, duszą ludzkiego życia i wszelkiego działania musi się stać modlitwa"1. W niniejszym artykule zamierzamy przedstawić naukę o modlitwie w ujęciu Jana Kasjana (ok. 360-433) w oparciu o jego Collationes (Rozmów dwadzieścia cztery $)^{2}$. Zanim to uczynimy, pragniemy już w tym miejscu zasygnalizować wpływ św. Jana Kasjana na św. Benedykta z Nursji (ok. 480-547) w dziedzinie modlitwy. Święty Patriarcha pozostawił w spadku swoim duchowym synom Regułę, w której modlitwa wysuwa się na pierwszy plan. Nie jest on jednak pionierem w wytyczaniu dróg doskonalenia modlitwy, ale korzysta obficie z doświadczenia wielu mistrzów życia ascetyczno-mistycznego. Wśród nich ważne miejsce zajmuje również Jan Kasjan, którego dzieła zaleca jako cenną lekturę swoim synom ${ }^{3}$.

${ }^{1}$ Jan Pawet II o św. Benedykcie, Kraków 1981, s. 17.

2 Por. Collationes Patrum, PL 49, 477-1328 lub wydanie M. Petscheniga - CSEL 13 (Wien 1886) lub wydanie E. Pichery'ego - SCh 42, 54, 64 (Paris 1955, 1958, 1959), którym się posługujemy; przekład polski ks. L. Wrzoła (Jan Kasjan, Rozmów dwadzieścia cztery, POK 6-7, Poznań 1928-1929), z którego korzystamy.

${ }^{3}$ Por. Regula 73, 4-5, SCh 182, 673, tłum. A. Świderkówna (Św. Benedykt z Nursji, Reguta; św. Grzegorz Wielki, Dialogi. Księga II, Tyniec-Kraków 1994), s. 263: „A któraż księga świętych katolickich Ojców nie przynosi wyraźnych pouczeń, w jaki sposób mamy prostą drogą dążý do naszego Stwórcy? Czymże zaś są i Konferencje Ojców, i Ustawy, i ich żywoty, czymże Reguła św. ojca naszego Bazylego, jeśli nie narzędziami, z których pomocą mnisi, dobrzy i posłuszni, budują swoje cnoty"? 


\section{SZKOŁA MODLITWY, JEJ WARUNKI I RODZAJE}

Jan Kasjan wprowadzając czytelnika w zagadnienie modlitwy, podaje kilka możliwości, które twórczo wpływają na jej rozwój. Poszczególne środki inspirujące modlitwę posiadają niewyczerpaną głębię, z której można wydobywać wciąż nowe treści. Chodzi zwłaszcza o Pismo św., modlitwy wspólne oraz pouczenia Ojców.

1. Źródła natchnienia do modlitwy. Kasjan na podstawie własnego doświadczenia stwierdza, że najobfitszym źródłem, z którego należy czerpać natchnienie do modlitwy jest Pismo święte. W nim bowiem są zawarte „wszystkie te uczucia”, które rodzą się w naszej duszy ${ }^{4}$. Autor zaleca, aby uczyć się na pamięć Pisma św., a szczególnie Psalmów. Zachęca także do ich głębszego zrozumienia ${ }^{5}$. Obok historycznej treści akcentuje duchowy sens Biblii. W ten sposób chce wprowadzić czytelnika w ukrytą głębię Pisma świętego. Aby wniknąć w misterium Słowa, trzeba mieć czyste serce i czysty umysł, bo „niemożliwe jest, by umysł nieczysty osiągnął dar wiedzy duchowej”. Wśród ksiąg Starego Testamentu ważne miejsce $w$ inspiracji do modlitwy zajmuje Księga Psalmów. Nowy Testament zawiera również wiele fragmentów pobudzających do modlitewnej refleksji. Chodzi tu zwłaszcza o tekst modlitwy «Ojcze nasz» (Mt 6, 9-13), której nauczył nas Pan Jezus ${ }^{7}$. Jest to przykład modlitwy tryskającej z najczystszego źródła, albowiem pochodzi od samego Pana. Pismo św. jest według Kasjana niewyczerpanym źródłem modlitwy i lekarstwem na każdą chorobę duszy. Świadczy o tym fakt, że prawie na każdej stronie Collationes autor umieścił cytaty biblijne.

Jako drugą pomoc w rozwoju modlitwy obok Pisma św. stawia nasz Autor modlitwy mnichów, „którzy mieszkają wspólnie w zgromadzeniu klasztornym pod kierunkiem jednego przełożonego" 8 . Zdarza się, że jeden werset jakiegoś Psalmu, który zakonnicy śpiewają, daje „okazję do modlitwy płomiennej”. Czasem melodyjny głos któregoś z braci „rozbudza duszę zasłuchanych do żarliwości”10. Autor wyraża przekonanie, że wspólne nabożeństwa dostarczają dla modlących się wielu sposobności, które za łaską Bożą mogą rozbudzić oziębłość naszej duszy" "11. Wspólne nabożeństwa były powodem spontanicznych porywów serca i duszy mnichów. Ale były też bodźce innego rodzaju.

\footnotetext{
${ }^{4}$ Por. Collationes X 11, 6, SCh 54, 93, POK 6, 346.

5 Por. tamże XIV 1,1, SCh 54, 183, POK 7, 107

${ }^{6}$ Tamże XIV 10, 1, SCh 54, 195, POK 7, 121.

7 Por. tamże IX 25.

${ }^{8}$ Tamże XVIII 4, 2, SCh 64, 14, POK 7, 240.

${ }^{9}$ Tamże IX 26, 1, SCh 54, 62, POK 6, 309.

10 Tamże.

11 Tamże IX 26, 2, SCh 54, 63, POK 6, 309.
} 
Kasjan wspomina na przykład śmierć któregoś z braci, wzywającą do pokornej modlitwy $^{12}$.

Trzecim źródłem, z którego należy czerpać, aby udoskonalić swą modlitwę, są według Kasjana pouczenia Ojców pustyni. Autor odwiedzał wielu takich Ojców i od nich uczył się modlitwy. Chciał poznać pustelników, „których sława rozeszła się już po całym świecie" ${ }^{\text {"13 }}$. Warto w tym miejscu zwrócić uwagę na pewne wzajemne powiązanie tych trzech źródeł modlitwy. Podobnie jak Pismo św., a zwłaszcza Psalmy, były używane podczas liturgii, tak po wspólnym nabożeństwie miały miejsce pouczenia Ojców. Jan Kasjan wspomina o tym dosyć często pisząc, że ,po nabożeństwie wieczornym, łaknąc obiecanej nauki, usiedliśmy znowu" ${ }^{14}$. Jednak nie tylko słuchanie Ojców i rozmowy z nimi dostarczały Kasjanowi pokarmu duchowego. Jego modlitewne doświadczenie rozwijało się również wtedy, gdy obserwował ich święte życie. Uważał bowiem, że w ten sposób „,najłatwiej znaleźć ową ewangeliczną perłę"15.

2. Warunki dobrej modlitwy. Zdaniem Kasjana, aby wejść na drogę modlitwy i by się dobrze modlić, winniśmy spełnić pewne zasadnicze wymagania, bez których nie ma autentycznej modlitwy. A oto warunki dobrej modlitwy według niego.

Pierwszym z nich jest wiara. Pobudza ona naszą gorliwość i uzdalnia do podjęcia pierwszych wyrzeczeń na drodze do doskonałości ${ }^{16}$. W ujęciu Kasjana wiara jest nie tylko drogą prowadzącą do Stwórcy, ale i źródłem zjednoczenia człowieka z Bogiem ${ }^{17}$. Autor podkreśla, jak ważną rolę spełnia wiara podczas modlitwy i stwierdza, że od niej zależy, w jakim stopniu będziemy wysłuchani $^{18}$.

Drugim warunkiem jest czystość serca. Jest ona według naszego Autora drogą prowadzącą do uświęcenia człowieka ${ }^{19}$. Aby osiągnąć upragniony stan czystości serca, trzeba podjąć wiele wyrzeczeń. Dla jej zdobycia warto opuścić rodziców, ojczyznę, wyzbyć się bogactwa, radości tego świata i szukać jej w samotności, wśród postów, pośród czuwania, czytania, w ciągłej pracy ${ }^{20}$. Kasjan zaznacza, że dla uzyskania pełnej czystości serca musimy uwolnić się

${ }^{12}$ Por. tamże. ,Niemniej zgon jakiegoś brata lub drogiej nam osoby porywał nas, jak wiemy, do zupelnego skruszenia".

${ }^{13}$ Tamże XI 1, SCh 54, 101, POK 7, 9.

14 Tamże XV 1, 1, SCh 54, 209, POK 7, 139.

15 Tamże XI 2, 2, SCh 54, 102, POK 7, 10.

${ }^{16}$ Por. tamże III $7,1$.

${ }^{17}$ Por. tamże VI 3,1.

${ }^{18}$ Por. tamże IX 32, SCh 54, 66, POK 6, 314: „W tej mierze bowiem zasłużymy sobie na wysłuchanie i tyle otrzymamy, ile będzie w nas wiary, iż Bóg patrzy na nas i pomóc nam może".

${ }^{19}$ Por. tamże I 5, 2, SCh 42, 82, POK 6, 14.

${ }^{20}$ Por. tamże I 7, 1. 
od wszystkich wad i namiętności, wyrażając przekonanie, iż czystość serca jest możliwa dzięki intensywnej pracy człowieka nad sobą, przy ciągłej współpracy $\mathrm{z}$ łaską Bożą ${ }^{21}$. Między modlitwą, a stałą czystością serca, istnieje jego zdaniem pewna wzajemna i nierozerwalna łączność, gdyż ,jak cała budowa cnót dąży do udoskonalenia modlitwy, tak też jeżeli modlitwa nie wzniosła się do szczytu, zabraknie i cnotom owej spójni i łączności, bez której żadną miarą mocno i stale trwać nie mogą" ${ }^{22}$. „Wszelka doskonałość serca zdąża do jednego celu, którym jest ciągła, nieprzerwana i wytrwała modlitwa" 23 .

Następnym warunkiem dobrej modlitwy w interpretacji Kasjana jest pokora. Jest ona „mistrzynią wszelkich cnót, najsilniejszym fundamentem budowy niebieskiej, właściwym i najwspanialszym darem Zbawiciela"24. Pokora polega także na szukaniu rady i na posłuszeństwie, albowiem „nikt nie ma polegać na sądzie własnym, lecz powinien się zawsze zdawać na zdanie starszych" "25. Należy też unikać wszelkich pochwał. Myśli upokarzające, jego zdaniem, są bardzo pożyteczne dla człowieka, gdyż dzięki nim może ustrzec się próżności $^{26}$.

Skupienie jest kolejnym warunkiem dobrej modlitwy. Zależy ono w dużej mierze od samego człowieka, który ma wpływ na to, czy w jego sercu „powstają myśli święte i wzniosłe, czy też ziemskie i cielesne" ${ }^{27}$. Dlatego powinniśmy strzec swego umysłu od wszelkich rozproszeń, aby przez wewnętrzne skupienie dążyć wytrwale do „oglądania rzeczy duchowych”28. Skupieniu sprzyja czytanie świętych tekstów, nocne czuwania, nieustanna modlitwa oraz praktykowanie surowych wymagań, jakie niesie ze sobą życie na pustyni ${ }^{29}$. Autor jest zdania, że jeśli chcemy być skoncentrowani na modlitwie, to powinniśmy unikać rozproszeń przed jej rozpoczęciem, „bo cokolwiek wstąpi do naszej duszy przed modlitwą, to koniecznie będzie się nam przypominało podczas modłów"30.

Kasjan, jako ostatni warunek dobrej modlitwy, wymienia dystans wobec świata. Polega on przede wszystkim na dobrowolnym wyrzeczeniu się tego, co przekracza miarę koniecznego codziennego pokarmu i podstawowych potrzeb ciała $^{31}$.

\footnotetext{
${ }^{21}$ Por. tamże XII $4,1$.

${ }^{22}$ Tamże IX 2, 1, SCh 54, 40, POK 6, 284.

23 Tamże, POK 6, 283.

24 Tamże XV 7, 2, SCh 54, 217, POK 7, 147

25 Tamże II 10, 1, SCh 42, 120, POK 6, 58.

26 Por. tamże III 2, 2.

27 Tamze I 17, 2, SCh 42, 98, POK 6, 32.

28 Tamże IX 3, 2, SCh 54, 42, POK 6, 285.

${ }^{29}$ Por. tamze IV $12,4$.

30 Tamże IX 3, 3, SCh 54, 42, POK 6, 286.

${ }^{31}$ Por. tamże IX 5, 4.
} 
3. Rodzaje modlitwy. Autor powołując się na św. Pawła $(1 \mathrm{Tm} 2,1)$ wymienia cztery rodzaje modlitwy. Są to: „błagania (obsecrationes), modlitwy (orationes), przyczyniania (postulationes), dziękowania (gratiarum actiones) ${ }^{\$ 32}$.

Błaganiu autor poświęca najmniej miejsca. Jest ono prośbą człowieka skierowaną do Boga o przebaczenie popełnionych grzechów. Kasjan zwraca uwagę w tym błaganiu na dyspozycyjność człowieka, na jego skruchę i szczere przyznanie się do niechlubnej przeszłości naznaczonej grzechem. Ten rodzaj modlitwy praktykują ci, „których trapią jeszcze bodźce i wyrzuty sumienia”33.

Najdłużej Kasjan zatrzymuje się nad modlitwami, które umieścił na drugim miejscu. „W modlitwach ofiarujemy lub ślubujemy coś Bogu, albo obiecujemy, że swoje postanowienia będziemy wiernie realizować w życiu" ${ }^{34}$. Do tych słów przysięgi dodaje jednak przestrogę, która dotyczy konsekwencji związanych $\mathrm{z}$ niewypełnieniem złożonych obietnic ${ }^{35}$. Zdaniem autora modlimy się, gdy całym sercem chcemy służyć tylko Bogu ${ }^{36}$. Modlitwą jest także podjęcie walki $\mathrm{z}$ wadami gniewu lub smutku ${ }^{37}$; ten rodzaj modlitwy praktykują ci, którzy ,,już w życiu duchowym postąpili i dążą do cnoty" 38 .

Przyczynianie się według Jana Kasjana jest modlitwą wstawienniczą: w ten sposób modlą się ludzie gorliwi o chwałę Bożą i zatroskani o dobro bliźnich, wstawiają się do Boga za swoich bliskich, za sprawujących władzę oraz modlą się o pokój na całej ziemi ${ }^{39}$. Ten zaś rodzaj modlitwy zanoszą do Boga ci, którzy wywiązują się ze złożonych przed Nim obietnic ${ }^{40}$.

Modlitwę dziękczynną autor umieszcza na czwartym miejscu. W niej człowiek staje przed Bogiem z czystym sercem i umysłem, przepełniony wdzięcznością za wszystkie Jego łaski ${ }^{41}$. Jednakże dopiero obietnice Boże dotyczące życia wiecznego są przyczyną modlitwy płomiennej ${ }^{42}$. Tak modlą się ci, , którzy już wydarli z serca ciernie karzącego sumienia"43.

Jan Kasjan stwierdza, że Pan Jezus używał wszystkich tych czterech rodzajów modlitwy i to On ich nas nauczył, aby każdy z nich odmawiać ,,przy różnych sposobnościach" ${ }^{44}$. Autor uważa, że doskonała modlitwa może zawierać je

32 Tamże IX 9, 1, SCh 54, 49, POK 6, 293.

${ }^{33}$ Tamże IX 15, 1, SCh 54, 52, POK 6, 297

${ }^{34}$ Tamże IX 12, 1, SCh 54, 50, POK 6, 295.

35 Por. tamże IX 12, 2.

${ }^{36}$ Por. tamże IX 12, 1.

37 Por. tamże.

38 Tamże IX 12, 1, SCh 54, 50, POK 6, 295

${ }^{39}$ Por. tamże IX 13.

${ }^{40}$ Por. tamże IX $15,1$.

${ }^{41}$ Por. tamże IX 14.

42 Por. tamże IX 15, 1

${ }_{43}$ Tamże IX 15, 1, SCh 54, 52, POK 6, 297

${ }^{44}$ Tamże IX 17, 3, SCh 54, 54, POK 6, 300. 
wszystkie naraz. Podobnie uczynił św. Paweł w liście do Efezjan, chcąc nas pouczyć, jak te cztery rodzaje modlitwy można połączyć w jednym błaganiu.

\section{WYŻSZY STOPIEŃ MODLITWY}

1. «Ojcze nasz» w interpretacji Kasjana. Zdaniem Kasjana «Modlitwa Pańska» jest stanem modlitwy wyższym i wznioślejszym od wszystkich czterech rodzajów modlitwy, które ją poprzedziły ${ }^{45}$. Autor we wstępie komentarza do «Modlitwy Pańskiej» pisze, że traktuje «Ojcze nasz» jako wyższy stan modlitwy o charakterze mistycznym. Istota tego stanu polega „na kontemplacji Boga samego i na gorącym do Niego przywiązaniu" ${ }^{46}$.

Autor zwracając uwagę na pierwsze słowa «Modlitwy Pańskiej» podkreśla, iż chrześcijanin powinien widzieć w Bogu, Panu wszechświata, Ojca, a siebie jako Jego dziecko ${ }^{47}$. Wezwanie «któryś jest w niebiesiech» ma nam przypominać, że my jako dzieci przebywamy obecnie na wygnaniu, oddaleni od Ojca. Ziemia bowiem według Kasjana jest krainą oddaloną od nieba, a oddalenie to rodzi tęsknotę dzieci za Ojcem ${ }^{48}$. Przestrzega przy tym, byśmy nie utracili dziedzictwa, które zostało przygotowane dla wiernych synów ${ }^{49}$. Jest zdania, że „gdy podniesiemy się na ten stopień synostwa [...] nie będziemy już błagali o korzyści dla siebie, lecz wszystkie pragnienia skierujemy ku chwale Ojca naszego" 50 . Wynika z tego, że warunkiem wypowiedzenia sercem pierwszej prośby «święć się Imię Twoje» jest według autora przeżycie godności synostwa Bożego. Tylko człowiek, który jest świadomy tego ciągłego związku z Bogiem, może przestawić życie z troski o swoją chwałę, na troskę o chwałę Ojca ${ }^{51}$. Jako konkretny przykład takiego postępowania Kasjan podaje św. Pawła, który modląc się w duchu «Ojcze nasz», gotów jest być nawet „daleko od Chrystusa”, gdyby przez to „wzrosła chwała Ojca Jego" ${ }^{\prime 2}$.

W drugiej prośbie «Przyjdź Królestwo Twoje» w opinii autora „dusza doskonale czysta wyraża pragnienie, by Królestwo jej Ojca jak najrychlej nadeszło" "53. Prośba ta może być wypowiadana tylko przez dusze doskonałe, które wykorzeniły w sobie wady, a nabyły cnoty; nie ośmieli się jej wypowiedzieć

${ }^{45}$ Por. tamże IX $18,1$.

46 Tamże IX 18, 1, SCh 54, 55, POK 6, 300.

${ }^{47}$ Por. tamże.

48 Por. tamże IX 18, 2, SCh 54, 55, POK 6, 301: „Powinniśmy więc uciekać stąd z obrzydzeniem, a śpieszyć raczej z największą tęsknotą do owej krainy, gdzie bawi Ojciec nasz".

${ }^{49}$ Tamże IX 18, 3, SCh 54, 55, POK 6, 301.

50 Tamże IX 18, 3, SCh 54, 55, POK 6, 301.

${ }^{51}$ Por. tamże.

52 Tamże.

53 Tamże IX 19, 3, SCh 54, 57, POK 6, 303. 
człowiek występny, ponieważ wie, że czeka go kara za to, iż nie skorzystał $z$ wielkiej godności, jaką jest przybrane synostwo Boże $\mathrm{e}^{54}$. Kasjan stwierdza, ze istnieje jeszcze inne Królestwo, które jest upragnionym przedmiotem duszy czystej, a jest nim Królestwo eschatologiczne, „które Pan przyobiecał ogólnie wszystkim doskonałym" ${ }^{25}$.

Według autora „nie można modlić się o rzecz większą” od tej, która zawarta jest w prośbie «bądź wola Twoja» ${ }^{56}$. Jest to prośba synów, w której zwracają się do Ojca w tym celu, aby „,sprawy ziemskie dorównywały niebieskim”, chodzi więc tu o to, by tak ,jak Aniołowie w niebie spełniają wolę Bożą", tak też podobnie postępowali ludzie na ziemi ${ }^{57}$.

Przez chleb Kasjan rozumie łaskę, jakiej Bóg udziela ludziom pobożnym. W prośbie «Chleba naszego» podkreśla „zacność i istotę tego chleba, jego wielkość i świętość” oraz uważa, że bez tego pokarmu ,ani jednego dnia nie możemy zachować życia duchowego" "58. Dlatego powinniśmy często się modlić, aby Bóg go nam udzielił. Kto bowiem codziennie wzmacnia się tym chlebem na ziemi, temu Bóg użyczy go w życiu przyszłym. Jeśli natomiast ktoś pozbawia się tego pokarmu $\mathrm{z}$ własnej winy w tym życiu, „ten nie będzie mógł ani w przyszłym w nim uczestniczyć $" 59$.

Zdaniem autora w słowach «Odpuść nam nasze winy» zawarty jest wzór modlitwy, a także sposób postępowania miły Bogu ${ }^{60}$. Polega on na przebaczeniu wszystkim, którzy wobec nas zawinili. Do pełni przebaczenia należy również odpowiedzialność za grzeszników. Warunkiem otrzymania miłosierdzia jest wybaczenie i zapomnienie doznanych krzywd. Pedagogia Boża jest bowiem taka, że odpowiada miłosierdziem na miłosierdzie, a sądem za brak miłosierdzia.

Według Kasjana «Nie wódź nas na pokuszenie», to prośba człowieka skierowana do Boga Ojca, której celem nie jest oddalenie wszelkiej pokusy, ale jedynie to, aby Bóg nie dozwolił, „byśmy pokusie ulegli”61. Pan Bóg dopuszcza kuszenie szatana, aby wypróbować w nas cnotę cierpliwości, gdyż przeciwności rodzą jeszcze większą wytrwałość. Ostatnia prośba "Zbaw nas od złego» ponawia poprzednie wezwanie, by w walce ze złem Bóg nas wspomagał. Jedynie pomoc ze strony Boga zapewnia nam wytrwałość i wyjście z pokusy.

«Modlitwa Pańska» zdaniem Jana Kasjana ma charakter wybitnie nadprzyrodzony ${ }^{62}$; jest to modlitwa najdoskonalsza, ponieważ pochodzi od samego

\footnotetext{
${ }^{54}$ Por. tamże.

55 Tamże IX 19, SCh 54, 57, POK 6, 303.

56 Tamże IX 20, 1, SCh 54, 57, POK 6, 303.

57 Tamże.

58 Tamże IX 21, 1, SCh 54, 58, POK 6, 304.

59 Tamże IX 21, 2, SCh 54, 58, POK 6, 305.

${ }^{60}$ Por. tamże IX 22, 1, SCh 54, 59, POK 6, 305.

61 Tamże IX 23, 1, SCh 54, 60, POK 6, 307.

62 Por. tamże IX 24.
} 
Chrystusa $^{63}$. Dla kogo «Ojcze nasz» stanie się regułą życia, ten wkrótce, zdaniem autora, wejdzie na wysoki stopień zjednoczenia z Bogiem ${ }^{64}$. Taka interpretacja «Modlitwy Pańskiej» w duchu nadprzyrodzonym i mistycznym odbiega nieco od interpretacji, jakie przed Kasjanem na Zachodzie podawali Tertulian, św. Cyprian i św. Augustyn ${ }^{65}$; ci bowiem mieli na uwadze bardziej względy duszpasterskie niż mistyczne. Jan Kasjan, zapowiada nowy sposób interpretacji «Ojcze nasz», który później znajdziemy w pismach mistyków, szczególnie św. Teresy Wielkiej.

2. Kontemplacja. Zdaniem Kasjana powołanie zakonnika i wszelka jego „doskonałość serca zdążają do jednego celu, mianowicie do ciągłej, nieprzerwanej i wytrwałej modlitwy"66. Według niego poznanie Boga przez podziwianie Jego istoty nie jest możliwe podczas ziemskiego życia człowieka: takie poznanie jest nam wprawdzie ,przyobiecane, ale dotąd jeszcze ukryte w nadziei" ${ }^{67}$. Nasz autor uważa, że obecne wpatrywanie się w Boga, czyli kontemplacja, może się dokonywać na trzech płaszczyznach. Poznanie Boga na pierwszej płaszczyźnie dokonuje się przez rozważanie oraz podziwianie wielkości i piękna stworzonego przez Boga wszechświata. Nasze doświadczenie religijne rozwija się także wtedy, gdy jesteśmy świadkami Bożej sprawiedliwości i codziennej Jego Opatrzności ${ }^{68}$. Drugą płaszczyzną, na której spotykamy się ze Stwórcą, jest Jego dobroć, cierpliwość i miłosierdzie. Doświadczamy ich na sobie, gdy na przykład otrzymujemy odpuszczenie grzechów. Według Jana Kasjana środki prowadzące do zbawienia są darem Bożym dla tych, których Bóg „chce przybrać za synów”69. Kontemplacja, zdaniem autora, jest dziełem Boga w człowieku, a jednocześnie zależy także od ,jakości naszego życia i czystości serca" ${ }^{70}$. To ostatnie zdanie dotyczy, trzeciej płaszczyzny poznania Boga. Autor właśnie na niej skupia swoją uwagę, uważając, że życie człowieka zgodne $z$ wymaganiami Ewangelii posiada decydujący wpływ na jego dalszy rozwój duchowy. Konkretnym przykładem, który może nam posłużyć za wzór w dążeniu do kontemplacji, jest postawa Marii z Ewangelii. Była ona zajęta jedynie słuchaniem nauki Jezusa i trwała wiernie u Jego nóg. Jan Kasjan pochwala takie podejście do modlitwy i sądzi, że ,serce nasze niewzruszenie

63 Por. tamże IX 25.

64 Por. tamże.

65 Por. Tertullianus, De oratione, CCL 1, 255-274, tłum. W. Kania, PSP 5 (Warszawa 1970), 114-132; Cyprianus, De dominica oratione, CSEL 3/1, 265-294, thum. J. Czuj, POK 19 (Poznań 1937), 224-251; Augustinus, Oratio 58 (De oratione Dominica), PL 38, 393-400, thum. A. Bober, Wykład Modlitwy Pańskiej, „Znak” 27(1975) nr 256, 1345-1353.

66 Tamże IX 2, 1, SCh 54, 40, POK 6, 283.

67 Tamże I 15, 1, SCh 42, 96, POK 6, 30.

${ }^{68}$ Por. tamże.

69 Tamże I 152, SCh 42, 97, POK 6, 31.

70 Tamże I 15, 3, SCh 42, 97, POK 6, 31. 
zawsze powinno dążyć do takiego zadania, by umysł trwał przy rzeczach Boskich i przy Bogu"71. Inne zaś cnoty i uczynki, chociaż potrzebne, mają znaczenie drugoplanowe. Siostra Marii Marta mimo swego trudu nie otrzymała pochwały, która przypadła w udziale Marii. Zasadnicze bowiem dobro umieścił Pan w kontemplacji. Dla autora jest to wysoki stopień życia duchowego, który osiąga się nie tylko własnym wysiłkiem, lecz przede wszystkim przy pomocy laski Bożej $^{72}$. Jan Kasjan jest zdania, że wszystkie zajęcia mnichów i ich kontakty z ludźmi powinny być przeniknięte nieustanną modlitwą. Głównym zadaniem zakonnika, na którym ma on skupić całą swoją uwagę, jest to, aby już na ziemi był godny zakosztować szczęścia podobnego do tego, jakiego będzie doświadczał w niebie "niby zadatku niebieskiego obcowania i chwały" ${ }^{73}$. Wiernym odzwierciedleniem takich wytrwałych poszukiwań Boga byli dla autora mnisi żyjący na pustyni. Od nich to nauczył się on trwać stale przed Bogiem. Kasjan uważa za doskonałą taką modlitwę, podczas której modlący się zapomina o sobie, a nawet o tym, że się $\operatorname{modli}^{74}$.

\section{DOSKONALENIE MODLITWY}

Autor po przedstawieniu poszczególnych etapów modlitwy, rozpoczynając od jej podstaw, a kończąc na kontemplacji, podaje z kolei rady i przestrogi dotyczące opanowania sztuki modlitwy.

1. Wprowadzenie na drogę rozwoju modlitwy. Kasjan darzył wielkim szacunkiem Ojców pustyni, którzy uczyli go modlitwy ${ }^{75}$. Z jego relacji wynika, że Ojcowie „nie tak łatwo zgadzali się, by komu otworzyć bramę doskonałości”, chyba że ktoś prosił o to $\mathrm{z}$ wielką pokorą ${ }^{76}$. Mnisi z pietyzmem odnosili się do modlitwy, która prowadziła do zjednoczenia się z Bogiem. Dzielenie się uwagami na jej temat odbywało się z powagą i odpowiedzialnością, jakby przekazywali komuś bliskiemu w spadku bezcenny dar.

Autor zanim przelał na papier wskazania i przestrogi dotyczące nauki modlitwy, sam przeszedł tę drogę $e^{77}$. Kasjan jest zdania, że do tego przedsię-

71 Tamże I 8, 1, SCh 42, 85, POK 6, 17.

${ }^{72}$ Por. tamże I 8, 3.

73 Tamże X 7, 3, SCh 54, 81-82, POK 6, 333.

${ }^{74}$ Por. tamże IX 31, SCh 54, 66, POK 6, 313: „Nie jest to, mawiał on, doskonała modlitwa, póki zakonnik wie o sobie lub choćby tylko o tem, że się modli”.

${ }^{75}$ Por. tamże I 1, SCh 42, 78, POK 6, 9: „Bawiąc w pustyni scytyjskiej, gdzie przebywali najdoświadczeńsi ojcowie życia zakonnego i wszelka mieszkała doskonałość, udałem się do Ojca Mojżesza, pragnąc się utwierdzić jego nauką".

76 Tamże, SCh 42, 78-79, POK 6, 9.

77 Por. tamże. Praefatio 1, SCh 42, 73, POK 6, 3. 
wzięcia należy się zabrać „z umysłem pogodnym i chętnym” oraz odważnie znosić wszelkie trudności ${ }^{78}$. Podobnie jak rolnik „nie zważając na palące słońce ani na szrony i lody" wciąż dąży od zadania do zadania ${ }^{79}$. Najpierw oczyszcza ziemię ze wszystkich chwastów, następnie rozkrusza glebę i podejmuje się wszelkich trudów, aby zebrać obfite plony. Autor uważa, że podobny proces powinien mieć miejsce w pracy nad doskonaleniem modlitwy, którą „trzeba rozpocząć od łatwych podstaw" ${ }^{\prime 0}$. Mnichom rozpoczynającym życie wewnętrzne należy przekazywać odpowiednie rady, zwiększając z czasem wymagania. Kasjan ten początkowy okres porównuje do rozwoju niemowlęcia, któremu podaje się najpierw mleko, a w miarę jego wzrostu inne pokarmy ${ }^{81}$. W ten sposób i młody zakonnik będzie dążył „od prostych zasad obranej sztuki i przekroczy jej progi, i tak wnijdzie do wnętrza doskonałości”"82. Autor radzi początkującym, aby starali się o wypracowanie w sobie czystości serca, która prowadzi do nieprzerwanej modlitwy ${ }^{83}$. Następnie Kasjan zwraca się do nowicjusza z kolejnym wymaganiem, które polega na zamieszkaniu w pustelni, gdzie ma on podjąć walkę ze swoimi wadami i namiętnościami, czyli zmagać się ze „starym naszym człowiekiem”84. Pobyt w samotności jest radykalnym, ale potrzebnym pociągnięciem. Zdaniem naszego przewodnika po drogach doskonałości, tym, którzy zrozumieli podstawowe zasady i stałe przebywanie w celi, można przekazać kolejne wskazania. Kasjan zwraca się też do osób, które tak skupiają się na środkach, że stają się one dla nich celem. Wyrażając swoją opinię na ten temat uważa, że w takim przypadku jeśli „miłość będzie w nas nienaruszona", wówczas nie poniesiemy żadnej szkody, gdy opuścimy coś z praktyk drugorzędnych ${ }^{85}$. Omawia on także zagadnienie podejścia zakonnika do godziwej pracy. W przekonaniu naszego nauczyciela modlitwy, gdyby mnich nie chciał się jej podjąć, obawiając się rozproszeń z nią związanych i uparcie trwał w swoim postanowieniu, wówczas może „popaść w smutek lub gniew albo niechęć" ${ }^{86}$. W takim przypadku więcej poniósłby szkody $\mathrm{z}$ gniewu, niż miałby pożytku $\mathrm{z}$ tak rozumianej ascezy. W stanie takiego wewnętrznego napięcia spokojny dialog z Bogiem nie jest możliwy, „bo gdy czystość serca zostanie skażona, z tego powodu modlitwa poniesie uszczerbek"87. Podobnie jak jest $\mathrm{z}$ narzędziami codziennego użytku, które nie są po to, aby

\footnotetext{
8 Tamże.

79 Collatio I 2, 1, SCh 42, 79, POK 6, 10.

${ }^{80}$ Tamże X 8, 2, SCh 54, 82, POK 6, 334.

81 Por. tamże.

82 Tamże.

83 Por. tamże I 7, 2, SCh 42, 84, POK 6, 16.

${ }^{84}$ Tamże I 5, 3, SCh 42, 82, POK 6, 14

${ }^{85}$ Por. tamże I 7, 2, SCh 42, 84, POK 6, 16

86 Tamze.

${ }^{87}$ Tamże IX 3, 4, SCh 54, 42, POK 6, 286.
} 
rdzewiały, lecz „aby posługiwać się nimi i osiągnąć właściwy cel”, tak też powinno być $z$ narzędziami dobrych uczynków w życiu duchowym ${ }^{88}$. Na drodze rozwoju modlitwy należy stale pamiętać o walce z myślami, które pochodzą „od szatana lub od nas samych" 89 . Kasjan zwraca się również do konkretnej grupy osób, szczególnie do zamożnych, którzy porzucili wszystko, aby naśladować Chrystusa. Wyrzekli się oni co prawda sławy i bogactwa, ale „tak nieraz zazdrośnie strzegą książki, że nie pozwalają nikomu zajrzeć do niej, ani się jej dotknąć" ". Autor jest zdania, że doskonałości nie można osiągnąć automatycznie przez wyzbycie się dóbr materialnych, czy też przez pozbawienie się zaszczytów. Jeśli bowiem zabraknie nam „,całkowitego wyrzeczenia się do wszelkiego przywiązania”, które osłabia czystość serca, wtedy następuje zahamowanie procesu modlitwy, zwłaszcza modlitwy nieustannej ${ }^{91}$. Kasjan uważa, że jeżeli ustrzeżemy serce „od szkodliwych namiętności”, wówczas będziemy czynili postępy w osiągnięciu doskonałości, która „polega na miłości” ${ }^{92}$, podkreślając, że ten stopień modlitwy jest bardzo ważny, ponieważ wprowadza czlowieka w kontemplację.

2. Sposób opanowania umiejętności modlitwy nieustannej. Autor po cennych ogólnych radach i przestrogach dotyczących nauki modlitwy, przechodzi do systematycznego wykładu metody doskonalenia modlitwy. Podaje prosty przykład wzięty z życia, będący jego zdaniem pomocą w uchwyceniu problemu, który szczegółowo będzie rozwijał. Postęp w modlitwie porównuje nasz przewodnik po drogach doskonałości do dzieci uczących się alfabetu. Uważa, że uczniowie rozpoczynający naukę w szkole nie zrozumieją jeszcze podstaw związanych z poznaniem liter, jeśli się im nie przekaże ,pewnych wzorów i przykładów"93. Po przyzwyczajeniu do nich swojego wzroku i wyćwiczeniu ręki przez „ciągłe ćwiczenie i codzienne naśladowanie”, ich wysiłki przynoszą oczekiwane owoce ${ }^{94}$. Również dla kontemplacji duchowej trzeba znaleźć taki wzór, ponieważ bez ,jakiejś rzeczy ściśle oznaczonej” trudno się skupićc ${ }^{95}$. Autor proponuje zakonnikowi, aby skoncentrował swe myśli na jednym wersecie zaczerpniętym z Księgi Psalmów (Ps 69, 2): «Boże, przybądź mi na pomoc: Panie, pospiesz się z pomocą Twą ku mnie» ${ }^{96}$, oraz radzi, by mnich odrzucał ,wszelką rozmaitość myśli”, a będzie to możliwe wówczas, gdy uwolni

\footnotetext{
88 Tamże I 7, 3, SCh 42, 85, POK 6, 17.

89 Tamże I 19, 1, SCh 42, 100, POK 6, 33.

90 Tamzie I 6, 2, SCh 42, 83, POK 6, 15.

91 Tamże.

92 Tamże.

93 Tamże X 10, 1, SCh 54, 85, POK 6, 337.

94 Tamże.

95 Tamże X 8, 5, SCh 54, 83, POK 6, 335.

96 Tamże X 10, 2, SCh 54, 85, POK 6, 337.
} 
się „od wszelkich trosk” związanych z potrzebami codziennej egzystencji ${ }^{97}$. W przekonaniu autora treść tego wezwania jest bardzo bogata, bo zawiera w sobie wszystkie uczucia, które mogą się zrodzić „w ludzkiej naturze”" ${ }^{\text {. Jest }}$ więc w nim obecny akt pokory, wyznanie prawdy o ograniczonych możliwościach człowieka, o jego słabościach i obawach, a jednocześnie o ufnej wierze w ciągłą obecność i opiekę Bożą oraz nadzieję wysłuchania usilnie zanoszonych próśb $^{99}$. Werset ten wyraża również miłość i „płomienne przywiązanie” do Boga $^{100}$. Kasjan wyznaje, że ten fragment zaczerpnięty z Księgi Psalmów jest „murem niezdobytym, pancerzem nieprzebitym i tarczą mocną" dla osób cierpiących z powodu pokus pochodzących od szatana ${ }^{101}$. Formułka ta chroni także od wszelkich grzesznych myśli, rozpaczy i smutku, a jednocześnie przestrzega przed pychą ${ }^{102}$.

Po przedstawieniu całej gamy wyrażeń zawartych w tym wersecie, przechodzi nasz autor do jego zastosowania w konkretnych sytuacjach życiowych. Zwraca przy tym uwagę na dobroczynne skutki, jakie przynosi jego częste powtarzanie. Autor przekazał nam przykłady, w których ukazuje jak wezwanie Psalmu «Boże, przybądź mi na pomoc: Panie, pośpiesz się z pomocą Twą ku mnie» wprowadza harmonię w życie człowieka wystawionego na różne pokusy, przywraca mu upragniony dialog z Bogiem i wprowadza na drogę modlitwy nieustannej. Nasz nauczyciel modlitwy każe posługiwać się tym wersetem zwłaszcza wtedy, gdy mnich ma na przykład pragnienie spożycia wyszukanych potraw nieznanych na pustyni lub chce przyśpieszyć godzinę regularnego posiłku, albo w czasie walki z nieczystymi myślami. Słowa tego Psalmu należy też wymawiać, aby uwolnić się od gniewu, chciwości i smutku ${ }^{103}$. Kasjan uważa, że po tych zmaganiach następuje wewnętrzne uciszenie. Ten duchowy pokój jest jego zdaniem „z nawiedzenia Ducha Świętego"104. Mnich zaczyna wtedy „opływać w bogactwo myśli duchowych" i „nagle przez oświecenie Pańskie” odsłaniają się przed nim ,najgłębsze i nigdy dotąd" nie dostrzeżone przez niego znaczenia Pisma świętego ${ }^{105}$. W przekonaniu autora, aby jak najdłużej utrzymać te myśli, trzeba często wołać do Boga: «Panie, pośpiesz się z pomocą Twą ku mnie». Po chwilach pełnych pokoju przychodzą nowe trudności, które nasilają się w miarę postępu na drodze do doskonałości. Jest to kolejny etap walki o zachowanie dotychczasowych osiągnięć duchowych. Aby jednak nie

\footnotetext{
97 Tamże.

98 Tamże X 10, 3, SCh 54, 85, POK 6, 338.

99 Por. tamże.

100 Tamże X 10, 4, SCh 54, 86, POK 6, 338.

101 Tamże.

102 Por. tamże.

${ }^{103}$ Por. tamze X 10, 6, SCh 54, 86, POK 6, 339.

104 Tamże X 10, 12, SCh 54, 87, POK 6, 341.

105 Tamże.
} 
stracić nadziei i nie ulec pokusom, należy posłużyć się fragmentem tego Psalmu. Po wielu doświadczeniach Bóg obdarza zakonnika odwagą, wtedy „,zuje się on otoczony” jakby niezliczoną liczbą Aniołów ${ }^{106}$. Zdaniem autora, zanim mnich nauczy się modlitwy nieustannej, przechodzi przez wiele etapów walki. Z każdej z nich wychodzi zwycięsko dzięki coraz ufniejszemu powtarzaniu tego wersetu. Kasjan zaleca, by tym wezwaniem posługiwać się bardzo często, zarówno w czasie pracy, podczas podróży, snu, jak również spełniając swoje codzienne obowiązki ${ }^{107}$. W opinii naszego mistrza stosowanie tego wiersza chroni w sposób niezawodny od wszelkich ataków szatana, oczyszcza duszę człowieka od nieuporządkowanych przywiązań oraz prowadzi „do owych niewidzialnych i niebieskich kontemplacji”, a także do „,bardzo niewielu znanej żarliwości modlitwy"108. Kasjan uważa, że tak wysoki stan modlitwy jest możliwy do osiągnięcia nie tylko dzięki ciągłemu rozważaniu tego wersetu, ale także wtedy, gdy zakonnik będzie żył bez przerwy tymi słowami, a wtedy na pewno dojdzie do modlitwy nieustannej ${ }^{109}$.

Celem tego artykułu była próba syntetycznego przedstawienia pouczeń na temat modlitwy podanych przez Jana Kasjana. Mając na uwadze całość niniejszego opracowania pozornie mogłoby się wydawać, ze Kasjan zbyt wiele miejsca poświęca wprowadzeniu do interesującego nas zagadnienia, natomiast za mało pisze na temat kontemplacji. Wydaje się, że taki stan rzeczy jest raczej zamierzony przez autora, który świadomie podaje na początku obszerne i solidne podstawy. Wie bowiem, że bez nich dobra modlitwa nie jest możliwa. Śledząc dokładnie tok myśli Jana Kasjana należy stwierdzić, że uderzająca jest w nich przejrzystość i jasność sformułowań. Klasycznym tego przykładem jest głęboka interpretacja «Modlitwy Pańskiej». Podobnie jest z doskonaleniem modlitwy. Kasjan nie podaje skomplikowanych metod, lecz ogranicza się do jednego zdania zaczerpniętego z Księgi Psalmów. Przy jego pomocy każe zwalczać wszelkie zagrożenia uniemożliwiające postęp modlitwy.

106 Por. tamze X 10, 13, SCh 54, 87, POK 6, 342.

107 Por. tamże X 10, 14, SCh 54, 87, POK 6, 342.

108 Tamże.

109 Por. tamże X 10, 15, SCh 54, 90, POK 6, 343: „A gdy wstaniesz i przystąpisz do jakichkolwiek koniecznych zatrudnień, niech i on się wyprostuje i stanie twą nieustanną modlitwą". 


\section{LA PRIÈRE SELON SAINT JEAN CASSIEN}

(Résumé)

Cet article veut présenter de façon synthétique les conseils de Jean Cassien au sujet de la prière d'après ses Conférences. L'exposé se divise en trois points. La première partie aborde les questions suivantes: l'école de la prière, ses conditions et ses différentes expressions. Les sources inspiratrices de la prière sont: l'Écriture Sainte, la prière communautaire, ainsi que les conseils des Pères du désert. Les conditions d'une bonne prière sont d'après Cassien: la foi, la pureté du coeur, l'humilité, le recueillement, l'éloignement du monde; sans cela une vraie prière n'est pas possible. Il est enfin parlé de quatre sortes de prière. La deuxième partie s'intitule: Le degré superieur de la prière; en lui est donné un commentaire du «Notre Père» à caractère mystique. Suit un entretien sur la contemplation, laquelle est l'oeuvre de Dieu fait homme, tout en dépendant également de la qualité de vie du priant. La troisième et dernière partie traite de la perfection de la prière. C'est un entretien introductif aux voies de développement de celle-ci. Enfin est abordée la question de l'apprentissage de la prière continuelle. Cassien ne nous a pas transmis une méthode compliquée; il se limite è un verset du livre des Psaumes: «Seigneur, viens à mon aide, hâte-toi de me secourir» (Ps 69, 2). Par cette exclamation Cassien veut que nous surmontions les obstacles au progrès de la prière. 